\title{
China versus Amerika Serikat: Interpretasi Rivalitas Keamanan Negara Adidaya Di Kawasan Asia Pasifik
}

\author{
M Najeri Al Syahrin \\ Universitas Muhammadiyah Kalimantan Timur
}

\begin{abstract}
ABSTRAK
Tulisan ini berupaya menggali makna isu rivalitas keamanan yang saat ini berlangsung antara negara adidaya Amerika Serikat dengan Cina di kawasan Asia Pasifik. Dengan kebangkitan Cina, hubungan Sino-AS telah menjadi semakin penting bagi stabilitas keamanan Asia Pasifik. Rivalitas keamanan yang terjadi antara kedua negara tersebut semacam 'ritual lama' yang kini diulang oleh 'jamaah baru'. Kontestasi politik dan keamanan yang sudah usai dengan berakhirnya Perang Dingin, secara langsung belum mampu menjadikan Amerika Serikat sebagai negara adidaya tunggal dan secara sepihak mampu terus menerus melakukan kontrol dinamika politik dunia. Hadirnya Cina memberikan alternatif dalam interaksi keamanan regional Asia Pasifik. Inisiasi strategi Cina dan respon aktif Amerika Serikat akan menentukan lanskap keamanan Asia Pasifik dalam beberapa dekade mendatang. Didorong oleh kebangkitan Cina tersebut, identitas Cina kini telah bergeser menjadi kekuatan besar yang intimidatif. Di satu sisi ia menjadi ancaman bagi kepentingan keamanan kawasan $A S$, di sisi lain Cina juga hadir sebagai kompetitor dalam kepentingan ekonomi $A S$.
\end{abstract}

Kata-kata kunci: Rivalitas keamanan, negara adidaya, Amerika Serikat dan Cina. kawasan Asia Pasifik.

This paper seeks to explore the meaning of security rivalry between US superpower and China's in the Asia Pacific region. With the rise of China, SinoUS relations have become increasingly important for Asia Pacific security stability. The security rivalry between the two countries is a kind of 'old ritual' that is now being repeated by the 'new congregation'. Political and security contestation that has ended with the end of the Cold War, has not been able to directly make the United States as a unipolar superpower and unilaterally able to continue in the dynamics of world politics controls. The presence of China provides an alternative to the Asia Pacific regional security architecture. The initiation of China's strategy and the active response of the United States will define the Asia Pacific security landscape in the coming decades. Encouraged by China's rise, Chinese identity has shifted into a massive, intimidating power. On the one hand, it poses a threat to the regional security interests of the US, on the other side China is also present as a competitor in the US economic interests.

Keywords: Security rivalry, superpower state, United States and China, Asia Pacific region. 
Kawasan Asia Pasifik merupakan pusat gravitasi keamanan global, kawasan ini merupakan kawasan paling strategis di dunia. Keamanan Internasional secara umum sangat ditentukan oleh bagaimana dinamika dan interaksi keamanan di kawasan ini. Kawasan Asia Pasifik juga merupakan kawasan yang paling dinamis pertumbuhan ekonominya. Posisi strategis tersebut menjadikan Asia Pasifik menjadi pusat aktivitas yang penting dalam percaturan politik global. Posisi strategis tersebut tentu akan mengakibatkan konstelasi konflik serta kerja sama yang tidak hanya melibatkan negara di kawasan tetapi juga melibatkan superpower state di luar kawasan. Peran aktif Amerika Serikat (AS) di kawasan ini telah menimbulkan berbagai spekulasi akan stabilitas keamanan kawasan ini. Pasca Perang Dingin, kebijakan keamanan AS banyak berfokus di kawasan Timur Tengah, AS seakan 'terlupakan' dengan kawasan Asia Pasifik. Kemunculan Cina dengan kekuatan ekonomi dan militernya dalam beberapa dekade terakhir, kini kembali menyadarkan AS tentang arti geopolitik dan geostrategi di Asia Pasifik. Rivalitas keamanan antara AS dan Cina akan menjadi isu regional terpenting dalam beberapa tahun kedepan (Bendini 2016, 23).

Secara historis, munculnya rivalitas negara adidaya cenderung akan mengakibatkan destabilisasi geopolitik. Kebangkitan Jerman pada akhir abad ke 19 mengakibatkan gesekan politik dengan AS dan Jepang. Perseteruan negara adidaya ini kemudian memuncak pada Perang Dunia II. Pada masa Perang Dingin, rivalitas AS dan Uni Soviet juga menyebabkan beberapa ketegangan keamanan di Eropa, Asia dan Amerika Latin. Tidak ada jawaban pasti kemudian bahwa peningkatan kekuatan Cina sebagai negara adidaya baru adalah sebuah pengecualian atas kondisi ini. Dampak rivalitas Cina terhadap AS kini telah berkembang dalam berbagai aspek, termasuk keamanan. Selama ini, sebagian besar transisi kekuasaan tersebut diakhiri dengan perang atau konflik. Dapatkah Cina dan AS menghindari kontes mematikan tersebut. Peningkatan kekuatan ekonomi dan militer Cina jelas akan menyebabkan gejolak geopolitik kawasan (Layne 2008).

Dalam konteks itulah studi tentang rivalitas keamanan ini diletakan, yaitu sebagai bagian dari dinamika dan konstelasi keamanan regional. Tulisan ini, beranjak dari pemaparan di atas, tidak berkehendak menggunakan konsep rivalitas keamanan terjadi secara luas dalam konteks keamanan global. Penggunaan terminologi rivalitas keamanan dikonsepsikan secara 'sempit' dalam lingkup regional, meskipun penulis memahami bahwa terdapat korelasi kuat antara keamanan global dengan keamanan regional. Namun, rivalitas keamanan merupakan konsep yang sangat kompleks. 
Interdepedensi keamanan akan sulit untuk "diurai" apabila digunakan dalam lingkup analisis global. Selain berupaya membaca peta konfigurasi persaingan dan rivalitas keamanan di Asia Pasifik, tulisan ini juga sedikit menyinggung tentang peranan ekonomi dalam konstelasi keamanan. Proses penciptaan stabilitas keamanan kawasan bukan semata sebuah upaya keamanan, tetapi juga ditentukan oleh konteks ekonomi. Karena itu perlu ada perspektif lain dalam memahami keterkaitan antara keamanan dan ekonomi dalam rivalitas negara adidaya di kawasan, pembahasan tersebut akan menjelaskan tentang bagaimana ekonomi 'bekerja' dalam kepentingan keamanan.

\section{Rivalitas Keamanan Negara Adidaya}

Peningkatan pengaruh Cina, semakin tak terelakkan, Cina telah menjadi pusat gravitasi baru di kawasan, sebuah kondisi yang harus diterima oleh AS. Selain mempunyai ambisi yang sangat besar, Cina juga didukung oleh kekuatan ekonomi sehingga upaya strategi rebalancing AS semakin sulit. Kesulitan tersebut antara lain juga terlihat dari kompleksnya permasalahan Cina dengan Taiwan, nuklir Korea Utara, permasalahan teritorial maritim Laut Cina Selatan yang mana, aspek-aspek tersebut berimplikasi pada kehadiran militer AS di kawasan Asia Pasifik (Al Syahrin 2015, 24-26). AS perlu membuat pilihan dilematis antara kepentingan domestiknya dan keunggulan militer di kawasan. Preferensi dan kepentingan Cina pada dasarnya memang akan konfrontatif dengan kepentingan AS karena kepentingan nasional yang utama bagi Cina adalah klaim teritorial Laut Cina Selatan dan Timur yang bertentangan dengan batas-batas maritim negara aliansi AS.

Meskipun kebijakan luar negeri Beijing menunjukkan strategi 'bermain baik' dan tidak secara langsung menantang kekuatan AS, tetapi ia tetap berusaha untuk mengalihkan kekuatan AS di wilayah tersebut. Kepentingan Cina adalah ingin membentuk tatanan politik dan keamanan baru di Asia, paling tidak dalam satu titik ia memiliki 'suara' yang setara dengan AS tentang masalah-masalah kawasan. Cina kurang bersedia untuk menerima status quo yang diyakini selama ini tidak adil dan lebih cenderung berpihak pada kepentingan AS. Ketakutan Cina yang paling penting dan mengkhawatirkan adalah pembangunan dan penempatan personil militer di sekitar wilayah teritorial yang mempunyai risiko melanggar batas wilayah Cina. Mengingat ketakutan ini, Cina telah mengeluarkan kebijakan yang mendefinisikan strategi militer dalam 
beberapa tahun kedepan. Ancaman terhadap klaim teritorialnya di Laut Cina Selatan adalah salah satu argumen yang ditekankan untuk kondisi ini. Cina berupaya menciptakan kekuatan angkatan laut yang mampu menyaingi Angkatan Laut AS dan negara aliansinya. Kontrol atas wilayah maritim yang diperebutkan ini telah menyebabkan adanya peningkatan ketegangan dengan AS (Bendini 2016, 17-18).

Menurut Departemen Pertahanan AS, Beijing berusaha untuk mengamankan status sebagai kekuatan besar dengan memperoleh keunggulan regional. Keunggulan regional ini diupayakan melalui keunggulan militer yang mampu menentang kepentingan AS. Meski Cina kini belum menjadi kekuatan militer global, setidaknya dalam upaya untuk mendekati status AS, Cina sudah mulai melakukannya. Bahkan jika Cina secara drastis terus meningkatkan anggaran belanja militer, keuntungan teknologi dan kapabilitas militer AS akan bisa untuk dicapai. Saat ini, Cina tampaknya masih terfokus pada doktrin 'active defense'. Doktrin ini menekankan pada pertahanan wilayah jika terjadi serangan dan invasi militer. Akibatnya, Cina saat ini menekankan pada modernisasi pasukan jarak dekat sehingga dapat sepenuhnya memfokuskan kapasitas militernya pada keamanan teritorial (Bendini 2016, 19-20). Saat ini, meskipun Cina belum bisa menyaingi kekuatan militer AS namun di kawasan Asia Pasifik, Cina telah menjadi kekuatan regional yang harus diperhitungkan. Selain itu, antarnegara adidaya masih kesulitan untuk memahami intensi dan niat satu sama lain. Sebagai contoh, tidak ada yang dapat memprediksi apa tujuan utama kebijakan keamanan Cina. Selain itu, kemampuan negara untuk berpikir strategis sebagai "Great Power" ternyata tidak menurun dengan berakhirnya Perang Dingin (Marsheimer 2001, 751).

Kelemahan kapasitas militer AS telah mulai semakin diuji oleh Cina. Beberapa kali Cina telah menunjukkan bukti upayanya untuk mengendalikan Laut Cina Selatan dengan menciptakan pulau buatan dan membangun pangkalan militer baru di wilayah tersebut. Cina melihat nilai strategis wilayah Laut Cina Selatan sebagai sarana untuk mencegah strategi pengepungan AS. Klaim ini dapat menimbulkan berbagai ketegangan tidak hanya dengan AS tetapi juga akan membahayakan hubungan Cina dengan negara tetangganya. Klaim teritorial ini menyiratkan adanya tabrakan kepentingan langsung dengan beberapa sekutu terdekat AS di kawasan, seperti Jepang, Filipina, dan Korea Selatan (Bendini 2016, 2022). Laut Cina Selatan dan Timur kini menjadi flashpoint kawasan yang telah menyebabkan hubungan antara Cina dan beberapa negara Asia Tenggara semakin menegangkan, khususnya Filiphina, Jepang, Vietnam, 
Malaysia, Brunei dan Indonesia. Kontestasi keamanan dan hukum yang terus berlanjut serta keterlibatan pihak ketiga menjadikan Laut Cina Selatan menjadi kawasan 'konflik masa depan' (Yang \& Li 2016, 136).

Pada November 2013, Presiden Xi kembali meluncurkan kebijakan yang agresif. ia mendeklarasikan zona identifikasi pertahanan udara di beberapa bagian Laut Cina Timur, yang memicu ketegangan dengan Korea Selatan, Taiwan, dan Jepang. Untuk kasus Taiwan, AS juga perlu secara cermat memetakan bagaimana mencapai tujuan dengan tidak secara konfrontatif bertentangan dengan kepentingan Cina. Di satu sisi, Washington perlu mempertahankan kehadiran militer dengan memberi dukungan pertahanan Taiwan untuk mencegah serangan juga sekaligus meyakinkan Beijing bahwa tujuan penjualan senjata dan kehadiran militernya tidak bertujuan mendukung pemisahan antara Taiwan dan Cina (Chen 2017, 11).

Dilema baru muncul jika AS tidak bisa secara tepat ikut campur tangan dalam upaya menghalangi Cina agar tidak memaksakan klaim teritorialnya. Perlombaan senjata kawasan mungkin akan dimulai untuk merespon ketidakmampuan AS tersebut. Namun, jika AS memutuskan untuk mengadopsi tindakan yang lebih tegas terhadap Cina, ini juga bisa mengarah pada potensi konflik yang membahayakan stabilitas keamanan kawasan. AS jelas tidak akan mengakui Cina dalam memproklamirkan kedaulatan atas pulau-pulau yang bersangkutan. Pertanyaannya kemudian adalah apakah klaim tersebut akan direspon dengan tindakan nyata dari AS. Cina kemungkinan akan memperkuat benteng militernya di wilayah yang di klaim, atau memberikan tekanan pada negara penuntut (seperti Taiwan, Jepang, Korea Selatan, Vietnam atau Filipina) untuk menguji komitmen AS dalam membantu sekutunya (Bendini 2016, 20-22). Masih harus dilihat apakah komitmen AS tersebut untuk memastikan kekuatan lautnya sendiri dan melindungi kepentingan sekutu militernya merupakan keterlibatan militer jangka panjang atau hanya gertakan untuk melindungi mitra keamanannya.

Kehadiran AS telah mengakar kuat di Asia Pasifik secara militer, politik dan ekonomi. Menyerahkan seluruh dominasi wilayah kepada Cina tentu membalik logika kebijakan lama yang dianut AS selama ini. Secara historis upaya AS untuk menghentikan dominasi negara lain dimulai sejak Perang Dunia II ketika berperang dengan Jepang. Selanjutnya kehadiran AS tetap dominan pada masa Perang Korea dan Perang Vietnam. Setidaknya untuk jangka menengah, mungkin Cina tidak terlalu kuat menekan AS untuk 
mundur dari basis militer dan jalinan aliansinya di Asia Pasifik. Dalam jangka panjang, kemungkinan besar hal tersebut akan dilakukan oleh Cina (Singh 2012; Bailey 2007, 139-140).

Beberapa faktor yang tidak pasti akan mempengaruhi keseimbangan kekuasaan masa depan di kawasan Asia-Pasifik. Pertumbuhan ekonomi Cina yang cepat, yang telah menjadi dorongan untuk pergeseran kekuasaan regional. Posisi AS di Asia juga masih belum pasti, tergantung pada pemulihan ekonomi yang berkelanjutan, dan komitmen yang kuat untuk rebalancing AS terhadap Asia. Jika faktor-faktor ini terus menguat, maka kemungkinan sistem kepemimpinan ganda masih terus berlanjut. Apapun masalahnya, sifat hubungan AS dan Cina yang tidak menentu akan memiliki dampak yang sangat besar pada kawasan untuk tahuntahun mendatang.

\section{Paradoks Kebijakan dan Upaya Harmonisasi}

Sejak kekalahan Jepang pada tahun 1945 dan terutama sejak berakhirnya Perang Dingin, AS telah memperlakukan Asia Pasifik hampir sebagai daerah 'teritorial pribadi' AS. Pengaturan kekuasaan di Asia Pasifik seperti perdagangan bebas, kebebasan navigasi maritim dan pemerintahan yang demokratis di beberapa negara mencirikan nilai-nilai yang sama dengan kepentingan AS (Dyer 2014). Sistem keamanan dimulai sejak tahun 1951 dengan penandatanganan Perjanjian San Francisco, perjanjian tersebut yang secara resmi menghentikan pendudukan Jepang serta upaya inisiasi aliansi keamanan antara kedua negara. Dua kesepakatan regionalisme ini, memelopori arsitektur keamanan kawasan Asia-Pasifik yang baru, yang kemudian diikuti oleh pakta bilateral dengan Korea Selatan, Taiwan, Thailand dan Filipina. Selain itu, implementasi kebijakan AS dalam dialog dengan ASEAN, Australia dan Selandia Baru serta forum Asia Pacific Economic Cooperations (APEC), ASEAN Plus dan KTT Asia Timur, dengan tegas mengaitkan sentralitas Asia-Pasifik sebagai arena diplomatik utama AS dalam kancah global (Chong \& Shang-su 2018). Peluncuran strategi pertahanan "Asia Pivot" pada era Obama telah menekankan bahwa tren kebijakan dan tantangan strategis AS berada di kawasan Asia Pasifik. Pada masa Pemerintahan Trump, Asia Pasifik juga masih merupakan kawasan yang selalu diperhatikan AS. Kehadiran Cina di Asia Pasifik yang dalam National Security Strategi (NSS) Pemerintahan Trump disebut sebagai "revisionis power" dan "strategic competitor' semakin menguatkan asumsi bahwa Asia Pasifik merupakan kawasan yang sangat penting bagi 
kepentingan keamanan AS (Jost 2017).

Terdapat paradoks menarik dalam hubungan rivalitas antara AS dan Cina selama ini. Apabila dibandingkan dengan masa Perang Dingin, konstestasi politik dan ideologi antara AS dan Uni Soviet dahulu berlangsung secara transparan, artinya masing-masing negara memang secara terbuka menyatakan terdapat 'benturan kepentingan' satu sama lain. Hal yang berbeda justru terjadi dengan Cina. AS selalu menempatkan Cina dalam posisi 'mitra strategis' perdagangan dan kerja sama ekonomi internasional sekaligus juga di sisi yang lain dianggap menjadi 'ancaman' dalam kepentingan keamanan. Paradoks ini bisa terlihat sejak kebijakan Asia Pivot pada masa Pemerintahan Obama. Obama berungkali menyatakan bahwa Asia Pivot bukan merupakan strategi untuk menahan pengaruh Cina di kawasan. Di sisi lain, para pejabat Cina juga menyatakan berulang kali bahwa mereka tidak punya niat untuk menghalangi kepentingan AS di Asia (Bendini 2016, 16). Kedua negara bagaimanapun, tentu memiliki strategi politikyang berbeda dan tampaknya, cenderung 'menyembunyikan' adanya kepentingan yang berbeda tersebut.

Beberapa contoh kebijakan AS lain juga mencerminkan paradoks ini. Pengerahan pasukan militer AS secara permanen di Australia serta upaya AS untuk mendiskusikan masalah Laut Cina Selatan dalam forum multilateral ASEAN Summit dianggap merupakan upaya untuk 'membendung' Cina. Selain itu, penguatan kapabilitas militer lima negara aliansi di kawasan Asia-Pasifik serta penyesuaian posisi pangkalan militer di sekitar wilayah Cina juga mencerminkan paradoks ini. Melihat strategi ini, sulit bagi AS untuk menyangkal bahwa kebijakan ini tidak mengarah kepada upaya pembendungan kekuatan Cina. Strategi counterbalancing di Asia Pasifik dinilai terlalu dini untuk diterapkan, karena strategi tersebut hanya cocok untuk era Perang Dingin dan dinilai kurang tepat apabila diterapkan di era milenial. Blokade ekonomi, strategi pengepungan, militerisasi serta perlombaan senjata sangat sulit dilakukan dalam politik global kontemporer. Tidak ada negara di kawasan yang menginginkan keadaan tersebut terjadi di kawasan meskipun di sisi lain mereka juga tidak ingin didominasi oleh kepentingan Cina. Jadi keterlibatan dan kerja sama dalam isu-isu transnasional tampaknya menjadi jalan terbaik ke depan bagi AS dan Cina (Schmidt 2014, 205-207).

Lingkungan strategis saat ini di Asia Pasifik dapat dicirikan oleh persaingan yang semakin ketat (dicampur dengan beberapa kerja sama) antara Cina dan AS tersebut. Pilihan kebijakan untuk saling mengakomodasi atau 
saling kontradiktif satu sama lain tentu akan memiliki efek spillover pada negara-negara lainnya (Huang 2015). Kedua negara idealnya saling menjadi 'responsible stakeholder' yang bertanggung jawab dalam sistem internasional. Meskipun di seberang lain, Cina dan AS masih memiliki banyak masalah yang belum diselesaikan, beberapa di antaranya secara langsung melibatkan kepentingan inti kedua negara serta negara aliansi AS. Isu-isu tersebut dapat menyebabkan kedua negara adidaya ini tersandung dalam sebuah bentrokan yang tidak diinginkan. Proses transisi kekuasaan keamanan maupun ekonomi akan terus menjadi faktor penentu dalam hubungan AS dan Cina. Analisis ini memegang sebuah proposisi kuat bahwa, meskipun Cina dan AS saling berkomitmen untuk masa depan yang damai, kedua negara ini memiliki banyak konflik kepentingan yang kompleks, dan melibatkan beberapa negara lain di kawasan, apabila hal ini tidak dikelola dengan baik, maka akan dapat menciptakan perang dan instabilitas regional (Lai 2011, 78-82).

Paradoks yang selanjutnya terjadi dalam aspek ekonomi dan perdagangan. Meskipun AS dan Cina sering terlibat perseteruan dalam penanganan konflik dan masalah keamanan di Asia Pasifik seperti permasalahan nuklir Semenanjung Korea, krisis Taiwan dan sengketa maritim Laut Cina Selatan dan Timur. Dalam kebijakan ekonomi, AS dan Cina cenderung bisa 'bermain baik'. Pembentukan komunikasi tingkat tinggi secara regular untuk mendukung koordinasi ekonomi antarnegara telah dibentuk sejak masa Pemerintahan Bush pada tahun 2005. Pada masa Pemerintahan Barack Obama, Cina mengirim delegasi terbesar pertama ke Washington dengan lebih dari 150 pejabat tingkat menteri. Pada Mei 2010, Menteri Luar Negeri Hillary Clinton dan Menteri Keuangan Timothy Geithner membalas kunjungan tersebut dengan mengirim 200 delegasi sebagai representasi Pemerintahan AS. Kunjungan tersebut merupakan kunjungan dengan delegasi terbesar yang pernah diutus Washington ke Beijing selama ini (Lai 2011, 82).

Dialog strategis pada era Pemerintahan Trump dimulai dengan kunjungan Xi Jinping ke Mar-a-Lago, Florida. Pertemuan tersebut mengindikasikan pesan penting, dua kekuatan ekonomi terbesar di dunia akan mengelola hubungan mereka dibawah prinsip 'Agreement to Disagreement'. Kesepakatan ini merupakan tekad bersama kedua negara untuk menyelesaikan perbedaan di bidang defisit perdagangan dan manipulasi mata uang (Zhao 2017). Pada titik ini, sebagian besar dialog masih memang masih berada pada tahap "pengujian kondisi". Artinya, kedua pihak masih saling merasa waspada satu sama lain serta berupaya untuk melindungi 
kepentingan vitalnya. Meskipun demikian, dialog adalah peluang aman dan realistis bagi kedua belah pihak untuk memahami posisi 'lawan' dan kepentingannya.

Dalam rentang tiga puluh tahun belakangan, Cina telah menjadi negara yang secara signifikan berpengaruh dalam setiap intrik politik dunia. Cina tampaknya menjadi calon potensial sebagai negara adikuasa, menawarkan alternatif baru bagi keunggulan AS dalam politik global. Kini Cina mulai secara terbuka menyatakan bahwa dengan kekuatan ekonominya, ia akan berupaya mendapatkan status sebagai Great Power (Bert 2003, 58). Kebangkitan Cina ini telah menghasilkan ikatan yang unik dengan AS. Keseimbangan yang kompleks antara kedua negara menghasilkan pola interaksi ketergantungan dan kepentingan yang berbeda. Pertama, kebangkitan Cina telah menyebabkan pembaruan dan peningkatan kolaborasi kestabilan tatanan dunia antara AS dan Cina yang telah membuahkan hasil pada sejumlah isu global khususnya dalam aspek ekonomi dan perdagangan. Kedua, kebangkitan Cina telah meningkatkan ketakutan dan ancaman. Perbedaan kepentingan dan orientasi politik antara AS dan Cina memungkinkan terjadinya konflik antarkedua negara (Bendini 2016, 4-5).

Sejak tahun 2008, sikap Cina telah berubah menjadi pendekatan yang lebih asertif dan bahkan kadang menghindar ketika terdapat potensi persaingan. Memang, Cina mengadopsi pendekatan yang sedikit revisionis pada beberapa kasus, yang dapat menyebabkan ketegangan lebih lanjut dengan pendekatan status quo dari AS. Dari kebangkitan G20 sebagai forum ekonomi utama dalam membahas isu-isu global, hingga pembentukan Bank Pembangunan dengan BRICS, Cina juga telah mendorong adanya lembaga multilateral alternatif. Meskipun Cina dan AS secara resmi memiliki hubungan politik yang berkembang berdasarkan kepercayaan dan sikap saling menghormati antarkedua negarea tetapi irisan kepentingan masih rentan terjadi (Bendini 2016, 16). Struktur kepemimpinan ganda tersebut tentu mempengaruhi distribusi kekuatan regional. Sebagai contoh, kekuatan ekonomi Cina yang meningkat sangat membantu dalam menjaga stabilitas ekonomi di Asia Pasifik ketika krisis keuangan global 2008. Ketika pertumbuhan ekonomi Cina mencatat rekor tinggi dapat mengimbangi pertumbuhan negatif AS, dengan demikian Cina mampu memainkan peran ekonomi yang stabil dan menguntungkan bagi negara-negara lain (Zhao 2017). 


\section{Geostrategi dan Geoekonomi Negara Adidaya di Asia Pasifik}

Selama beberapa dekade, AS mampu memainkan peran hegemonik yang sentral di wilayah Asia Pasifik. AS menjamin stabilitas keamanan, serta membina aliansi dan kemitraan politik. Selama beberapa dekade, stabilitas keamanan dan kemakmuran saling terkoordinasi dalam jangkauan AS. Hari ini, tatanan baru mulai bergesar dan memberi jalan bagi kekuatan baru dengan kehadiran Cina di kawasan (eds. Inoguchi \& Ikenberry 2013, 13). Hubungan antara AS dengan Cina merupakan hubungan paling penting dalam politik dunia. Teori transisi kekuasaan menunjukkan bahwa kekuatan yang meningkat dan rivalitas hegemoni cenderung sulit diselesaikan dengan jalan damai dan kondisi tersebut akan menciptakan sebuah tragedi politik (perang atau konflik). AS mengalami penurunan kekuatan (declining) atas meningkatnya pengaruh Cina dalam persaingan keamanan. Namun, pendapat berbeda juga menyatakan bahwa mengingat keterbukaan ekonominya, arus tatanan global akan mampu mengakomodasi kebangkitan Cina dengan cara damai. Tragedi atas transisi kekuasaan tersebut tidak dapat dihindari jika AS dan Cina tidak dapat mengatur hubungan bilateral mereka yang rumit. Melihat kondisi ini, tentu akan menarik apabila membandingkan pendekatan dan strategi yang dilakukan kedua negara untuk mencapai kepentingan geopolitik di tengah kompleksnya kondisi rivalitas tersebut.

Hingga akhir tahun 1980-an Cina tidak memiliki kebijakan kawasan yang integratif dan secara khusus berfokus pada kawasan Asia Pasifik. Namun kini, Cina mulai meningkatkan fokus strategis hubungan bilateral dan kebijakan luar negeri yang lebih berorientasi pada kepentingan geostrategi (Hwang \& Dongxiao 2010, 107). Dengan status kekuatan ekonomi dan militer yang terus meningkat, Cina juga telah mengusulkan serangkaian inisiatif untuk mengelola hubungannya secara khusus dengan AS. Pada tahun 2012, selama perjalanan ke Washington, Xi Jinping menyerukan pembentukan flatform 'A New Type of Great Power Relations In The 21st Century'. Flatform ini mewakili inisiatif Cina untuk menghindari konfrontasi antardua kekuatan adidaya. Bagi beberapa cendekiawan Cina, prakarsa Cina ini adalah eksplorasi lanjutan dari prakarsa 'G2' dan 'Chimerica' yang diperkenalkan pada tahun 2008 untuk mengelola hubungan antara Beijing dan Washington. Saat ini, diplomasi proaktif Xi Jinping sedang berusaha untuk membentuk kembali hubungan SinoAS di masa depan dengan mempromosikan gagasan 'New Type of Great Power Relations'. Beberapa berpendapat bahwa konsep ini adalah sebuah 'perangkap' untuk AS yang direncanakan oleh Cina. Sementara beberapa 
pihak yang optimis tetap menganggap pendekatan ini sebagai kesempatan untuk mengintegrasikan Cina dalam tatanan global serta mencari landasan ikatan yang kuat (durable foundation) dalam hubungan AS-Cina (Zheng 2016, 423-425).

Sikap AS terhadap flatform kebijakan Cina ini masih ambigu dan cenderung menentangnya. Sejauh ini, pemerintahan Trump belum menunjukkan dukungan yang jelas terhadap konsep yang diciptakan oleh Cina ini. Meskipun demikian, propaganda Cina secara eksplisit dan implisit menunjukkan bahwa AS telah 'menerimanya'. Ini menunjukkan harapan dan antusiasme tinggi dalam mempromosikan konsep ini. Terdapat alasan bagi Cina untuk berharap AS 'mengakui' konsep tersebut. Dari perspektif strategis, ketika AS menerima konsep ini, berarti secara langsung ia mengakui status Cina sebagai 'great power', dan dengan demikian, pengakuan AS akan dilihat sebagai kemenangan diplomasi Cina di bawah kepemimpinan Xi (Zheng 2016, 431).

Xi Jinping merupakan pemimpin yang sangat kuat dan inovatif dalam melihat tata kelola global. Dia tampak berbeda dari para pendahulunya, Xi bergerak lebih cepat dan tegas dalam pencapaian kepentingan utama Cina. Kepentingan-kepentingan tersebut antara lain, memaksimalkan pengaruh Cina di wilayah Pasifik Barat, membangun hubungan ekonomi Cina dengan negara-negara di kawasan, reunifikasi dengan Taiwan dan menegaskan klaim teritorial Cina di Laut Cina Selatan dan Timur yang diupayakan dengan penguatan teknologi maritim dan kapabilitas militer. Kebijakan ekonomi regional Cina juga dirancang untuk meningkatkan inter-konektivitas sambil terus memainkan peran dalam mekanisme multilateral yang ada. Xi juga berupaya mempertahankan hubungan yang positif dengan AS sambil terus mempersiapkan kemungkinan adanya persaingan strategis. Tindakan Xi tersebut telah dirancang untuk tujuan dalam aktivitas ini, tetapi dengan kemampuan Cina yang semakin meluas telah terjadi kekhawatiran apakah peningkatannya akan berlangsung damai atau mengancam stabilitas keamanan (Bader 2016).

Kekhawatiran akan ancaman ekspansi pengaruh Cina tersebut secara 'halus' ditampik Cina dengan strategi 'Low Profile' dan 'Peaceful Development' yang diinisiasi sejak masa Deng Xiaoping. Selama beberapa dekade kebijakan tersebut sudah berjalan efektif. Tren terbaru dalam diplomasi Cina dibawah kepemimpinan Jinping menunjukkan bahwa strategi Cina terhadap Asia mengedepankan pendekatan 'Harmonious Asia'. Frasa ini mengandung arti 'kebersamaan' yang tentu sangat 
menarik bagi masyarakat kawasan. Untuk mengembangkan strategi ini, Cina menggunakan tiga jalur pendekatan, yaitu kerja sama ekonomi, jalinan kemitraan strategis, dan keamanan multilateral. Pada jalur strategi yang pertama, kerja sama ekonomi Cina tidak hanya mendekati negaranegara Asia Pasifik sebagai mitra bilateral, tetapi juga menggunakan jalur multilateral untuk mengembangkan dan mengintensifkan hubungan ekonominya. Misalnya, peningkatan proporsi perdagangan eksternal dan investasi. Cina juga melakukan Free Trade Agreement (FTA) dengan ASEAN dan masih terus melakukan koordinasi perdagangan dengan Australia, India, dan Korea Selatan. Cina juga terus memperkuat kerja sama sub-wilayah di sepanjang aliran sungai Mekong. Pendekatan Cina dalam One Belt One Road (OBOR) juga sangat mencirikan strategi ini. (Zeng 2016, 432)

Selanjutnya, pendekatan kedua dari 'Harmonious Asia' adalah membangun kemitraan strategis untuk hidup berdampingan secara damai dengan negara-negara tetangga. Cina selalu berupaya untuk memperkuat hubungan bilateral dengan negara-negara melalui jalinan kemitraan strategis ini. Meskipun ada banyak pesimisme terutama dalam klaim Cina di kasus Laut Cina Selatan. Pendekatan kolektif ini dinilai masih cukup efektif untuk menggandeng negara-negara di kawasan. Komponen ketiga dari pendekatan Cina adalah jalinan keamanan multilateral. Awalnya, pola pikir Cina masih sangat klasik, bahwa organisasi multilateral akan bertentangan dengan kepentingan nasional, tetapi dengan Kongres ke16 Partai Komunis Cina pada tahun 2002, menjadi sebuah referensi baru atas perubahan pola pikir Cina yang lebih optimistik. Tidak hanya aktif berpartisipasi dalam forum-forum seperti APEC, ASEAN+3, ASEAN+1, tetapi juga aktif dalam Asean Regional Forum (ARF), East Asian Submit (EAS), serta inisiasi keamanan maritim bersama dalam inisiatif OBOR. Lebih jauh lagi, Cina mengerahkan pasukan penjaga perdamaian untuk daerah-daerah konflik serta melanjutkan latihan militer gabungan dengan negara-negara lain. Ringkasnya, 'Harmonious Asia' secara efektif mencerminkan nilai kebersamaan universal dalam strategi diplomatik Cina kontemporer (Hwang \& Dongxiao 2010, 109-110).

Munculnya pendekatan geoekonomi Cina tersebut merupakan faktor penentu dalam mencapai kepentingan geostrategi. Pertumbuhan ekonomi yang kuat dan ekspansi pasar domestik Cina yang semakin meluas, menjadikan Cina sebagai produser barang terbesar di Asia. Cina juga telah memperkuat daya saing ekspornya sehingga menyebabkan perubahan dalam transaksi ekonomi negara-negara tetangga di Asia (ed. Goh \& 
Simon 2008, 53). Kebijakan ekonomi regional tersebut pada akhirnya mampu mengukuhkan Cina sebagai kekuatan baru yang berpengaruh di kawasan. Dengan absennya AS dalam Trans Pacific Partnership (TPP) dan kini muncul inisiatif baru OBOR kini AS jelas 'menyerahkan' pengaruh ekonominya di kawasan Asia Pasifik kepada Cina (Kuo 2017). Rencana ambisius infrastruktur OBOR Cina diimplementasikan dalam pembangunan bendungan, jalan, pemukiman, konstruksi kereta api berkecepatan tinggi yang akan mengintegrasikan wilayah Selatan dan Barat Cina. Dalam pengertian ini, Asia Pasifik dapat dikatakan telah 'didominasi' oleh Cina. Dengan perkembangan konstruksi jalur kereta api Asia, negara seperti Kazakhstan, Uzbekistan dan Turkmenistan akan mendapatkan akses komersial laut melalui pelabuhan Iran. Dengan cara ini, OBOR bahkan dapat dikatakan membuka kembali rute kereta api Indo-Pasifik dengan kendali di bawah Cina (Chong \& Shang-su 2018).

Dua peristiwa penting tersebut memiliki pengaruh signifikan terhadap pengaturan keamanan yang ada di Asia Pasifik. Hasil dari OBOR, yang dipimpin oleh Xi Jinping, dan Donald Trump yang meninggalkan kesepakatan TPP, mengakibatkan banyak negara Asia yang mengorientasikan kembali kebijakan lama mereka terhadap kedua negara tersebut. Komitmen tidak jelas AS terhadap sekutu tradisional di Asia, ditambah dengan tawaran miliaran dolar dalam investasi infrastruktur oleh Cina, berpotensi mengubah peta politik kawasan Asia Pasifik selama ini. Kebijakan Trump 'America First' dan kebijakan Xi tentang 'deep pockets' untuk negara tetangga Cina telah membuat beberapa loyalis AS mengkalibrasi ulang jalinan aliansi mereka. Pergeseran yang paling mencolok terlihat dari kebijakan Presiden Filipina Rodrigo Duterte. Meskipun memiliki masalah maritim dan sengketa perbatasan dengan Cina di Laut Cina Selatan, Filipina secara terbuka telah menandatangani beberapa perjanjian ekonomi bilateral dengan Cina, bahkan Cina kembali menyumbang senjata untuk Filiphina, yang digunakan dalam konflik untuk memberantas terorisme di Mindanao (Khasru 2017).

Thailand dan Indonesia juga telah ditarik lebih dekat dalam pengaruh politik Cina melalui pendeketan ekonomi. Pemerintah militer Thailand tidak memiliki hubungan yang nyaman dengan AS terutama sejak pemerintahan Obama dan sekarang Cina dan Thailand bekerja sama dalam proyek kereta api berkecepatan tinggi senilai \$5,1 miliar (Khasru, 2017). Indonesia, di era Joko Widodo juga semakin menjalin hubungan yang erat dengan Cina. Cina terlibat aktif dalam pembangunan infrastruktur di Indonesia, yang meliputi pembangunan 24 pelabuhan, 15 pelabuhan 
udara, pembangunan jalan sepanjang $1.000 \mathrm{~km}$, pembangunan rel kereta sepanjang $8.700 \mathrm{~km}$, serta pembangunan powerplan berkapasitas 35 ribu megawatt (Setkab, 2015). Selain itu, Pemerintah Indonesia melalui Badan Koordinasi Penanaman Modal (BKPM) kembali menawarkan sejumlah proyek infrastruktur bernilai Rp 217 triliun kepada Cina melalui Roadshow Investasi (market sounding) di dua kota besar Cina yaitu Beijing dan Tianjin (Republika 2017). Jika Filipina, Indonesia, Thailand, dan negara-negara lain semakin dekat dengan Cina, ini semua berpotensi mengguncang dasar-dasar orientasi geopolitik negara-negara ASEAN.

Sampai pada titik ini, strategi Cina ini telah cukup membuahkan hasil. Geostrategi yang dilakukan oleh Cina merupakan siasat untuk menangkap berbagai peluang kepentingan yang dapat dimaksimalkan di kawasan. Dengan kata lain, melalui pendekatan ini Cina dapat menghadapi ketatnya persaingan dengan negara besar lainnya (Dugis 2015, 15). Namun, pendekatan Cina ini juga mendapatkan beberapa tantangan khususnya dengan AS. Pertama, apabila AS di bawah Trump mampu melakukan reorientasi kebijakan yang lebih berorientasi pada smart power dan bisa memberikan keuntungan ekonomi bagi seluruh negara kawasan maka hal itu bisa merubah arsitektur hegemoni ekonomi yang selama ini sudah dilakukan Cina. Selain itu, AS juga bisa 'menggunakan' Jepang untuk menciptakan strategi diplomasi kawasan dan saling berkolaborasi untuk menjadi saingan strategis Cina. Jika Cina kesulitan mengharmonisasikan hubungan dengan dengan negara-negara kawasan maka AS dan Jepang bisa mengambil alih 'kemudi' kerja sama ekonomi kawasan (Hwang \& Dongxiao 2010, 108-112).

Restorasi kekuatan AS melalui slogan "Make America Great Again" dan "American First" merupakan strategi kunci yang utama dalam kebijakan AS di bawah kepemimpinan Trump. Di antara fokus kebijakan yang menjadi prioritas Trump di Asia Pasifik adalah mengedepankan kepentingan nasional. Bagi Trump, AS harus mendapatkan penghormatan dengan menunjukan dominasi total atas semua negara. Dalam upaya untuk melakukan dominasi tersebut, AS harus memproyeksikan kepentingan dengan membangun kekuatan dan kemampuan negara untuk bertindak dalam politik internasional yang tidak dibatasi oleh aturan internasional dan kesepakatan aliansi (Yuliantoro 2016, 198-201).

Atas dasar itulah, strategi terbaru AS dalam National Security Strategy (NSS) menyatakan secara terbuka bahwa Cina menantang kekuatan AS. Secara khusus, NSS mengklaim bahwa Cina berusaha untuk 'menggeser 
pengaruh' AS di kawasan Indo-Pasifik dengan memperluas jangkauan ekonomi dibawah kendali Cina. Pergeseran dalam kebijakan luar negeri AS tersebut tidak hanya sangat konfrontatif terhadap Cina, tetapi juga secara umum menggeser pendekatan soft power yang sudah dikembangkan sejak masa Obama. Namun, kontradiksi antara teks strategi, pesan diplomatik serta retorika Presiden Donald Trump cenderung dinilai akan menjadikan kebijakan AS selalu bersifat fluktuatif dan labil (Jost, 2017).

Secara keseluruhan, perbedaan yang paling mencolok dari kebijakan geoekonomi AS adalah keluarnya dalam kesepakatan TPP. Hal tersebut berimplikasi pada perubahan orientasi geoekonomi negaranegara kawasan. Jepang dan Australia kemudian memimpin dalam Comprehensive and Progressive Agreement for Trans-Pacific Partnership (CPTPP atau TPP-11) tanpa AS. Perjanjian ini diharapkan mulai berlaku pada awal 2019, setelah diratifikasi oleh setidaknya enam dari 11 anggota. Indonesia, Thailand dan Inggris telah menyatakan minatnya untuk bergabung dengan kesepakatan tersebut. Trump mengatakan bahwa dia terbuka untuk bergabung kembali dengan perjanjian tersebut jika hanya melibatkan kesepakatan yang lebih baik untuk AS. Kondisi mungkin sulit terjadi dalam waktu dekat (Rana \& Ji 2018).

Ditinjau dari tujuannya, strategi dan pendekatan antara Cina dan AS memiliki beberapa perbedaan mendasar. AS cenderung lebih isolasionis dan protektif, sementara Cina lebih kolektif dan kooperatif. Citra Xi Jinping sebagai pemimpin yang inovatif juga semakin menguatkan strategi Cina ini semakin efektif. Disisi lain, retorika Trump yang cenderung pragmatis dan kontroversial, semakin menyulitkan negara aliansi AS. Selain itu, Cina juga didukung oleh kekuatan ekonomi yang cenderung stabil dalam beberapa tahun belakangan sehingga memungkinkan banyak negara di kawasan mendekat ke Cina karena orientasi ekonomi tersebut. Meskipun banyak kecaman terhadap kurangnya transparansi dan diplomasi jebakan utang dari Cina, banyak negara berkembang yang membutuhkan pembiayaan investasi melihat Cina dengan kebijakan ekonominya sebagai sebuah proposisi yang menarik, tanpa disadari kebijakan ekonomi tersebut semakin menguatkan pengaruh politik dan keamanan Cina di kawasan Asia Pasifik.

\section{Simpulan}


Tidak mudah untuk mengambil sebuah simpulan tunggal dan jelas mengenai rivalitas keamanan antar negara adidaya di kawasan Asia Pasifik. Rivalitas keamanan merupakan kondisi dan intrik yang sangat kompleks dengan berbagai aspek pendukungnya yang kadang justru berada di luar lingkaran keamanan itu sendiri, aspek ekonomi adalah salah satu contohnya. Penulis mencoba menguraikan rivalitas tersebut dengan menunjukan bahwa dengan kebangkitan Cina, hubungan SinoAS telah menjadi semakin penting dan mungkin berbahaya bagi stabilitas keamanan kawasan. Kontestasi politik dan keamanan yang sudah usai dengan berakhirnya Perang Dingin, secara langsung belum mampusecara lama-menjadikan AS sebagai negara adidaya yang selalu bisa mengatur dunia secara 'tunggal'. Hadirnya Cina memberikan alternatif dalam interaksi keamanan regional. Akibatnya, pergeseran ini memicu perdebatan kontemporer bagaimana mengelola konflik dan hegemoni antar dua kekuatan tersebut.

Strategi New Type of Great Power Relations dan Harmonious Asia telah menjadi sinyal positif tentang perilaku bertanggung jawab Cina. Identitas Cina telah bergeser menjadi kekuatan besar yang menjadi tantangan dalam kepentingan ekonomi dan perdagangan AS. Meskipun di sisi lain, seperti yang banyak diulas dalam tulisan ini, kebangkitan Cina lebih banyak 'mengancam' kepentingan keamanan AS. Di satu sisi, pola hubungan rivalitas keamanan ini menjadi unik, karena cenderung berbeda dengan rivalitas keamanan antara AS dan Uni Soviet ketika masa Perang Dingin. Meskipun demikian, seperti yang diungkapkan juga oleh artikel ini, AS dan Cina harus sama-sama saling terus mencari cara agar hubungan strategis antar kedua negara tidak menimbulkan efek negatif terhadap stabilitas keamanan kawasan.

Hampir dapat dipastikan bahwa kita akan menyaksikan lebih banyak peningkatan kekuatan Cina di tatanan regional masa depan, yang kini telah ditunjukkan oleh inisiatif dari One Belt One Road. Pemahaman yang lebih baik tentang kebangkitan Cina serta niat strategisnya membutuhkan pengamatan lebih dekat dalam setiap langkah Cina. Tantangan selanjutnya adalah AS perlu mencari keseimbangan antara 'menerima' peran global yang lebih besar bagi Cina sambil terus membangun cara untuk 'melawan' pemaksaan kepentingan dari Cina. Singkat kata, di sinilah rivalitas sebagai kompromi-kompromi keamanan justru menemukan arti pentingnya. Pendekatan yang masuk akal adalah dengan terus melibatkan Cina, untuk dapat memainkan peran yang lebih besar dalam mendukung sistem keamanan global. Upaya ini diharapkan akan mampu menurunkan esklasi persaingan dan saling mengamankan berbagai kepentingan antara AS dan Cina. 


\section{References}

\section{Buku}

Bailey, Jonathan. 2007. Great Power Strategy in Asia: Empire, Culture and Trade, 1905-2005. New York: Routledge.

Bert, Wayne. 2003. The United States, China and Southeast Asian Security: A Changing of the Guard. London: Palgrave Mcmillan.

Chen, Dean., 2017. US-China Rivalry and Taiwan's Mainland Policy Security, Nationalism, and the 1992 Consensus. Swiss: Palgrave Mcmillan.

Goh, Evelyn and Simon, Sheldon W. (eds.), 2008. China, The United States, And Southeast Asia: Contending Perspectives on Politics, Security, And Economics. New York: Routledge.

Inoguchi, Takashi and Ikenberry, G John. (eds.). 2013. The Troubled Triangle: Economic and Security Concerns for the United States, Japan, and China. New York: Palgrave Mcmillan.

Mearsheimer, John. 2001. The Tragedy of Great Power Politics. New York: Norton.

\section{Artikel Jurnal}

Dugis, Vinsensio. 2015. "Memahami Peningkatan Kehadiran China di Pasifik Selatan: Perspektif Realisme Stratejik”. Global \& Strategis, 9 (1): 1-18.

Hwang, Jaeho \& Dongxiao, Chen. 2010. "China's Harmonious Asia Strategy”. International Area Review, 13, (2): 1-20.

Schmidt, Johannes. 2014. “The Asia-Pacific Strategic Triangle: Unentangling the India, China, US Relations on Conflict and Security in South Asia". Journal of Asian Security and International Affairs, 1, (2) 203-222.

Yang, Fang. 2016. “Comparing China's Claims and Policies in the East and South China Seas: Implications for Regional Security”. Asian Security and International Affairs, 3, (2): 135-156.

Yuliantoro, Nur Rachmat. Et al. 2016. "Pemilihan Presiden Tahun 2016 dan Politik Luar Negeri Amerika Serikat”. Jurnal Hubungan Internasional, 5 (2):193-209.

Zeng, Jinghan. 2016. "Constructing A New Type of Great Power Relations: The State of Debate in China (1998-2014)". The British Journal of Politics and International Relations, 18 (2): 422-442. 


\section{Lain-Lain}

Bendini, Roberto. 2016. United States - China Relations: A Complex Balance Between Cooperation and Confrontation. Directorate General for External Policies Policy Department, European Union.

Lai, David. 2011. The United States and China in Power Transition. Strategic Studies Institute. Carlisle.

Layne, Christopher. 2008. China's Challenge to US Hegemony. Current History. Januari, pp. 13-16.

Al Syahrin, Najeri. 2015. Kompleksitas Keamanan Kawasan dan Implikasinya terhadap program Pengembangan Senjata Nuklir Korea Utara. Tesis Magister. Yogyakarta: Departemen Hubungan Internasional Universitas Gadjah Mada.

\section{Artikel Daring}

Bader, Jeffrey. 2016. "A Framework for U.S. Policy Toward China” (online). dalam https://www.brookings.edu/research/a-framework-for-u-spolicy-toward-china/ (diakses 9 Maret 2018)

Chong, Alan \& Shang-su, Wu. 2018. 'Indo-Pacific' vs 'Asia-Pacific': Contending Visions?” (online). dalam https://www.rsis.edu.sg/wpcontent/uploads/2018/02/CO18034.pdf (diakses 9 Maret 2018)

Dyer, Geoff. 2014. "US-China: Is This the New Cold War? The New Era of Military Competition in the Pacific Will Become the Defining Geopolitical Contest of the 21st" (online). dalam https://www.ft.com/ content/78920b2e-99ba-11e3-91cd-00144feab7de (diakses 12 April 2018)

Huang, David. 2015. "Building Security and Integration in The Asia Pacific" (online). dalam http://www.eastasiaforum.org/2015/o6/13/buildingsecurity-and-integration-in-the-asia-pacific/ (diakses 4 April 2018)

Jost, Tyler. 2017. "The New Pessimism of U.S. Strategy Towards China" (online). dalam https://warontherocks.com/2017/12/newpessimism-u-s-strategy-towards-china/ (diakses 29 Maret 2018)

Khasru, Syed Munir. 2017. "The Geopolitical Landscape of Asia Pacific Is Changing Dramatically. Here's How" (online). dalam https://www. weforum.org/agenda/2017/07/the-geopolitical-landscape-of-asiapacific-is-changing-dramatically-here-s-how/ (diakses 6 April 2018)

Kuo, Mercy. 2017. "US-China Economic Relations: Impact on the AsiaPacific Region" (online). dalam https://thediplomat.com/2017/06/ us-china-economic-relations-impact-on-the-asia-pacific-region/ 
(diakses 9 April 2018)

Rana, Pradumna \& Ji, Xianbai. 2018. "Asia Pacific Pivots Beyond a Trump-led America" (online) dalam http://www.eastasiaforum. org/2018/o4/17/asia-pacific-pivots-beyond-a-trump-led-america/ (diakses 11 Maret 2018)

Republika. 2017. "Indonesia Tawarkan Cina Proyek Infrastruktur Rp 217 Triliun" (online). dalam http://republika.co.id/berita/ekonomi/ makro/17/o7/28/otstly383-indonesia-tawarkan-cina-proyekinfrastruktur-rp-217-triliun (diakses 1 April 2018).

Sekretaris Kabinet. 2015. "RRT Akan Terlibat Dalam Pembangunan 24 Pelabuhan, 15 Airport, Dan 8.700 Km Jalan Kereta" (online). dalam http://setkab.go.id/rrt-akan-terlibat-dalam-pembangunan-24pelabuhan-15-airport-dan-8-700-km-jalan-kereta/ (diakses 9 April 2018).

Singh, Daljith.2012. "US-China dialogue process: prospects and implications" (online). dalam http://www.eastasiaforum. org/2012/11/o2/us-china-dialogue-process-prospects-andimplications/ (diakses 9 Maret 2018)

Zhao, Quansheng. 2017. "An Emerging U.S.-China Dual Leadership in Asia-Pacific" (online). dalam https://www.chinausfocus.com/foreignpolicy/an-emerging-us-china-dual leadership-in-asia-pacific (diakses 10 April 2018) 